Editorial

\title{
Explaining Secessionism: What Do We Really Know About It?
}

\author{
Ferran Requejo ${ }^{1, *}$ and Marc Sanjaume-Calvet ${ }^{1,2}$ \\ ${ }^{1}$ Department of Political and Social Sciences, Pompeu Fabra University, Spain; E-Mails: ferran.requejo@upf.edu (F.R.), \\ marc.sanjaume@upf.edu (M.S.-C.) \\ 2 Faculty of Law and Political Science, Open University of Catalonia, Spain \\ * Corresponding author
}

Submitted: 18 October 2021 | Published: 10 December 2021

\begin{abstract}
In this thematic issue we discuss what we really know about the explanations for secessionism. Over the last few decades, an increasing number of new analyses on secessionism have appeared, regarding both its normative and its empirical dimensions. We can distinguish at least three types of research questions that categorise the current analyses of secessionism: normative, explanatory, and pragmatic. Political theorists work mainly on the moral and political right to unilaterally secede, answering questions such as "under what conditions" this right is legitimate and "who" has this moral right (Requejo \& Sanjaume-Calvet, 2015; Sanjaume-Calvet, 2020). Despite the importance of normative theories, these approaches do not provide explanations for secessionism, although most of them are built on implicit explanations of these phenomena. The field of explanatory theories of secession focuses mainly on the individual and/or aggregate preconditions and variables that correlate (or not) with the presence (or absence) of secessionist movements in specific territories. Through our general guiding question-"what do we really know about the explanations for secessionism?" - we try to disentangle the current explanations of secessionism by using empirical analyses, combining comparative politics and case studies. We bring together several different analytical perspectives, from political economy, nationalism, electoral behaviour, and institutional studies. Beyond these empirical perspectives, the issue puts forward some normative implications based on what we know and what we do not know about the existence of secessionist claims.
\end{abstract}

\section{Keywords}

federalism; regionalism; secession; secessionism; theories of secession

Issue

This editorial is part of the issue "Secessionism in Liberal Democracies: What Do We Really Know About the Explanations of Secessionism?" edited by Ferran Requejo (Pompeu Fabra University, Spain) and Marc Sanjaume-Calvet (Pompeu Fabra University, Spain / Open University of Catalonia, Spain).

(C) 2021 by the authors; licensee Cogitatio (Lisbon, Portugal). This editorial is licensed under a Creative Commons Attribution 4.0 International License (CC BY).

\section{Introduction}

Describing, explaining, and developing theories about secessions and secessionism is crucial for understanding these phenomena better and for developing potential solutions to them. In recent years, in a context of globalisation and growing illiberal trends (Acemoglu \& Robinson, 2019; Levitsky \& Ziblatt, 2018; Norris \& Inglehart, 2019), certain intellectuals have upheld interpretations of secessionism that are sometimes based on misunderstandings, prejudices, or accepted ideas, rather than on specific empirical research. In this thematic issue we discuss what we really know about the explanations for secessionism. We address the subject by focusing on both individual and aggregate data in comparative politics, presented in a series of articles written by top researchers in this field.

\section{A Growing Field of Scholarly Literature}

Over the last few decades, an increasing number of new analyses on secessionism have appeared, regarding both its normative and its empirical dimensions. Two main interlinked factors explain the growing interest in 
this topic. Firstly, the fall of the Berlin Wall and the subsequent dissolution of the USSR, Yugoslavia, and Czechoslovakia led to the creation of several states, creating minorities and majorities in the new republics and fostering secessionism around the world (Lukic \& Lynch, 1996). Secondly, since the 1980 s, the academic debate on political liberalism has turned its interest to group rights and belonging (Bell, 1993; Requejo, 2001; Sandel, 1984). However, most normative and empirical analyses have generally followed parallel agendas, without a consistent epistemological balance existing between them.

We can distinguish at least three types of research questions that categorise the current analyses of secessionism: normative, explanatory, and pragmatic (see Table 1).

Political theorists work mainly on the moral and political right to unilaterally secede, answering questions such as "under what conditions" this right is legitimate and "who" has this moral right (Requejo \& Sanjaume-Calvet, 2015; Sanjaume-Calvet, 2020). That is, the normative approach to secession generally focuses on the legality, legitimacy, and/or permissibility of this phenomenon from a political and moral standpoint.

Despite the importance of normative theories, these approaches do not provide explanations for secessionism, although most of them are built on implicit explanations of these phenomena. For instance, justcause theories (Buchanan, 1991, 2004) assume that pro- independence movements emerge because of a perception of "lack of justice" among specific populations. There are thus moral criteria available to assess these demands and classify them as "vanity" or "just" secessions. For some reason that generally remains unexplained by these authors, "vanity" movements do not hold a valid claim, but often succeed in mobilising people for their cause. In a similar line of reasoning, "culturalist" theories assume that sub-national identities are the main driver of secessionism, but several sub-state identities without secessionist movements remain unexplained or are not considered as valid national identities.

This thematic issue explicitly focuses on explanatory approaches in order to consider the individual and collective causes of secessionism, and ends with some normative reflections based on the former explanatory empirical findings.

\section{Some Analytical Features}

The field of explanatory theories of secession focuses mainly on the individual and/or aggregate preconditions and variables that correlate (or not) with the presence (or absence) of secessionist movements in specific territories. This scholarly literature brings together quantitative and qualitative studies in political science with contributions from economics, sociology, international relations, historical studies, and political psychology.

Table 1. Approaches to secessionism.

\begin{tabular}{|c|c|c|c|}
\hline Approach & Research questions & Objectives & (Some) Analytical deficits \\
\hline Normative & $\begin{array}{l}\text { What is happening? } \\
\text { What should happen? }\end{array}$ & $\begin{array}{l}\text { To prescribe } \\
\text { - Legitimacy } \\
\text { - Legality } \\
\text { - National/cultural justice-individual } \\
\text { and collective rights and freedoms }\end{array}$ & $\begin{array}{l}\text { - Little empirical knowledge } \\
\text { - Idealism } \\
\text { - Moralism } \\
\text { - Legalism } \\
\text { - Implicit anthropologies } \\
\text { (mainly Kantian) }\end{array}$ \\
\hline Explanatory & $\begin{array}{l}\text { What is happening? } \\
\text { Why does it happen? }\end{array}$ & $\begin{array}{l}\text { To explain } \\
\text { - Individual approaches (social class, } \\
\text { gender, languages) } \\
\text { - Collective approaches (institutions, } \\
\text { economics, history) }\end{array}$ & $\begin{array}{l}\text { - Little theoretical knowledge } \\
\text { - Partial inferences } \\
\text { - Lack of clarity about } \\
\text { "preferences" and aggregative } \\
\text { methods } \\
\text { - Ambiguity of the relationship } \\
\text { between erklären vs. verstehen } \\
\text { scientific explanations } \\
\text { - Implicit anthropologies } \\
\text { (mainly Hobbesian) }\end{array}$ \\
\hline Pragmatic & $\begin{array}{l}\text { What is happening? } \\
\text { What is the best way } \\
\text { to manage the conflict? } \\
\text { How can we overcome } \\
\text { the problem? }\end{array}$ & $\begin{array}{l}\text { To find solutions } \\
\text { (short, mid, and long term) } \\
\text { - To hide, to marginalise, or to } \\
\text { minimise the conflict }\end{array}$ & $\begin{array}{l}\text { - Little empirical and theoretical } \\
\text { knowledge } \\
\text { - Localism } \\
\text { - Inflation of "path dependency" } \\
\text { features } \\
\text { - Short-term conclusions }\end{array}$ \\
\hline
\end{tabular}


While the authors generally use the term preconditions to mean the necessary characteristics of each group (such as the existence of an identity and a territory), they generally use variables to refer to contextual and/or changing contingent aspects that might influence the probability of success of each movement in mobilising people to support secession. Additionally, some theories go further than this and: (a) point to these movements' immediate triggers of conflict; and (b) try to explain how successful they are (to achieve an independent state or to remain part of their parent state; see Figure 1).

A plurality of preconditions, variables, and triggers may be identified. Depending on the theory followed, these elements play different roles and have more or less explanatory weight in the emergence of secessionism and the support for it: diversity in ethnicity and/or national identity (Hale, 2000; Hechter, 1992; Horowitz, 1981; Wood, 1981); relative isolation or other geographical aspects (Sorens, 2012); cultural, economic, and other kinds of perceived (or not) grievances (Griffiths \& Martinez, 2020); relative economic success or failure (Álvarez Pereira et al., 2018; Hechter, 1992; Webb, 2015; Wood, 1981); individual and collective socio-psychological characteristics (Basta, 2018; Dion, 1996); agency (Krause, 2017; Sanjaume-Calvet, 2021; Siroky et al., 2016); external recognition (Coggins, 2014; Griffiths \& Muro, 2020); and variation in state formation patterns and institutional past (Roeder, 2007; Webb, 2015).

These elements generally constitute the central argument of a given explanatory theory of secession (or specific study on this phenomenon), and they tend to interact with the other potential preconditions and/or variables in each author's analysis. Moreover, these elements are sometimes presented as the explanation for the upsurge of a certain movement, while at other times they are used to try and explain the degree of support for a movement or its success (both at individual and collec- tive levels). Obviously, in the empirical terrain, we usually observe a complex combination of these elements, one that might also change over time. It is evident that no single one of these theories is capable of encompassing a general or universal explanation of these kinds of movements across space and time.

Through our general guiding question-"what do we really know about the explanations for secessionism?"in this thematic issue we try to disentangle the current explanations of secessionism by using empirical analyses, combining comparative politics and case studies. We bring together several different analytical perspectives, from political economy, nationalism, electoral behaviour, and institutional studies. Beyond these empirical perspectives, the issue puts forward some normative implications (political theory) based on what we know and what we do not know about the existence of secessionist claims. In doing so, we aim to bridge the gap between normative and empirical approaches in the current literature on secessionism. This thematic issue includes contributions that analyse secessionism from individual, aggregate, and theoretical perspectives. The current Catalan context is the most frequently analysed empirical case in the articles that follow, although it is not the only one.

From an individual perspective which delves into the explanatory factors of secessionism, Jordi Muñoz refutes Piketty's "Catalan syndrome" through an analysis of the economic determinants of support for secessionism (Muñoz, 2021); Laia Balcells and Alexander Kuo work on "moderate voters," i.e., individuals that do not have a strong territorial preference (Balcells \& Kuo, 2021); Robert Liñeira performs a case study on Scotland and the "voting shock" valence effects of elections as critical junctures (Liñeira, 2021); Juan Rodríguez-Teruel and Astrid Barrio analyse the role of party and voter polarisation as "ethnic outbidding" dynamics (Rodríguez-Teruel \& Barrio, 2021); and the last contribution at the individual level

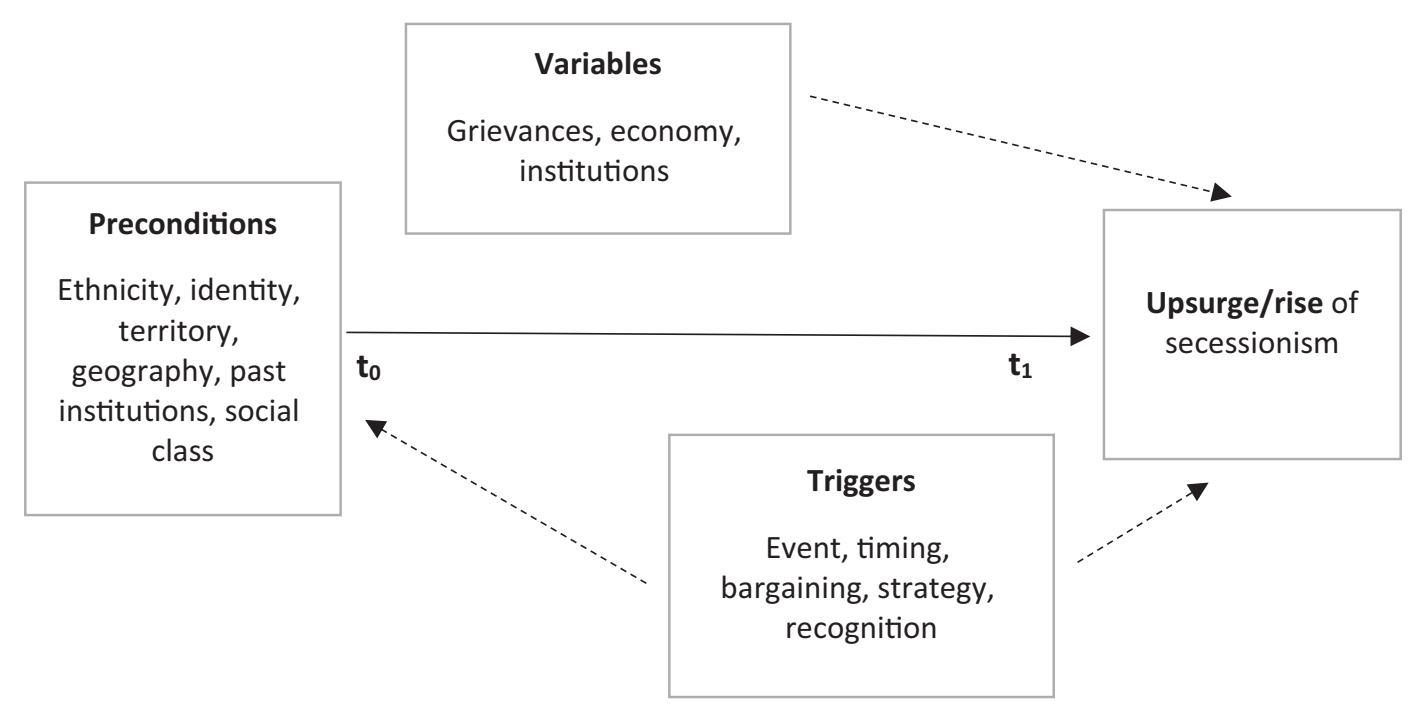

Figure 1. Main analytical elements of explanatory theories of secession. 
is from Jordi Argelaguet, who focuses on the impact of language on secessionism and anti-secessionism (Argelaguet, 2021).

From an aggregate perspective, Francesc Amat and Toni Rodon's article, and Anwen Elias and Núria FrancoGuillén's contribution move beyond the micro level and include comparative data (Amat \& Rodon, 2021; Elias \& Franco-Guillén, 2021). Amat and Rodon introduce a large- $\mathrm{N}$ perspective that tests the "commitment problem" thesis using a dataset of regional autonomy; Elias and Franco-Guillén focus on pro-independence parties and their discourses during the secessionist rise that occurred between 2008 and 2018 in Catalonia. Both articles point to some relevant aspects and disregarded other aspects that are present in the scholarly literature, namely political discourses and the (lack of) credibility of territorial agreements.

Finally, from a theoretical perspective, José L. Martí and Lluís Pérez-Lozano discuss existing normative theories of secession (Martí, 2021; Pérez-Lozano, 2021). Martí describes the normative obstacles of legitimately redrawing borders, and proposes a potential solution based on disagreement and consensus; Pérez-Lozano, also working on the notion of legitimacy, reflects on the Quebec case and the role of constitutional firewalls in dealing with secessionist claims in liberal democracies.

\section{Acknowledgments}

We are grateful to all participants at the workshop Explanatory Factors of Secessionisms held the 26th November 2020 at Institut d'Estudis de l'AutogovernSelf-Government Studies Institute (Barcelona). We acknowledge the financial support from two institutions, Institut d'Estudis de l'Autogovern (Generalitat de Catalunya) and Open University of Catalonia, for this thematic issue.

\section{Conflict of Interests}

The authors declare no conflict of interests.

\section{References}

Acemoglu, D., \& Robinson, J. A. (2019). The narrow corridor: States, societies, and the fate of liberty. Penguin.

Álvarez Pereira, B., Portos, M., \& Vourdas, J. (2018). Waving goodbye? The determinants of autonomism and secessionism in Western Europe. Regional Studies, 52(2), 197-211.

Amat, F., \& Rodon, T. (2021). Institutional commitment problems and regional autonomy: The Catalan case. Politics and Governance, 9(4), 439-452.

Argelaguet, J. (2021). The relevance of language as a predictor of the will for independence in Catalonia in 1996 and 2020. Politics and Governance, 9(4), 426-438.

Balcells, L., \& Kuo, A. (2021). Preferences in between:
Moderates in the Catalan secessionist conflict. Politics and Governance, 9(4), 386-398.

Basta, K. (2018). The state between minority and majority nationalism: Decentralization, symbolic recognition, and secessionist crises in Spain and Canada. Publius: The Journal of Federalism, 48(1), 51-75.

Bell, D. A. (1993). Communitarianism and its critics. Clarendon Press.

Buchanan, A. (1991). Secession: The morality of political divorce from Fort Sumter to Lithuania and Quebec. Westview Press.

Buchanan, A. (2004). Justice, legitimacy, and selfdetermination: Moral foundations for international law. Oxford University Press.

Coggins, B. (2014). Power politics and state formation in the twentieth century: The dynamics of recognition. Cambridge University Press.

Dion, S. (1996). Why is secession difficult in wellestablished democracies? Lessons from Quebec. British Journal of Political Science, 26(2), 269-283.

Elias, A., \& Franco-Guillén, N. (2021). Justifying secession in Catalonia: Resolving grievances or a means to a better future? Politics and Governance, 9(4), 453-464.

Griffiths, R. D., \& Martinez, A. (2020). Local conditions and the demand for independence: A dataset of secessionist grievances. Nations and Nationalism, 27(2), 580-590.

Griffiths, R. D., \& Muro, D. (2020). Strategies of secession and counter-secession. ECPR Press.

Hale, H. E. (2000). The parade of sovereignties: Testing theories of secession in the Soviet setting. British Journal of Political Science, 30(1), 31-56.

Hechter, M. (1992). The dynamics of secession. Acta Sociologica, 35(4), 267-283.

Horowitz, D. L. (1981). Patterns of ethnic separatism. Comparative Studies in Society and History, 23(2), 165-195.

Krause, P. (2017). Rebel power: Why national movements compete, fight, and win. Cornell University Press.

Levitsky, S., \& Ziblatt, D. (2018). How democracies die. Crown/Archetype.

Liñeira, R. (2021). Valence secession? Voting shocks and independence support in Scotland. Politics and Governance, 9(4), 399-411.

Lukic, R., \& Lynch, A. (1996). Europe from the Balkans to the Urals: The disintegration of Yugoslavia and the Soviet Union. SIPRI.

Martí, J. L. (2021). The democratic legitimacy of secession and the demos problem. Politics and Governance, 9(4), 465-474.

Muñoz, J. (2021). The Catalan syndrome? Revisiting the relationship between income and support for independence in Catalonia. Politics and Governance, 9(4), 376-385.

Norris, P., \& Inglehart, R. (2019). Cultural backlash: Trump, Brexit, and authoritarian populism. Cambridge University Press. 
Pérez-Lozano, L. (2021). An imperfect firewall: Quebec's constitutional right of secession as a device against domination. Politics and Governance, 9(4), 475-482.

Requejo, F. (2001). Democracy and national pluralism. Routledge.

Requejo, F., \& Sanjaume-Calvet, M. (2015). Recognition and political accommodation: From regionalism to secessionism-The Catalan case. In J.-F. Grégoire \& M. Jewkes (Eds.), Recognition and redistribution in multinational federations (pp. 107-132). Leuven University Press.

Rodríguez-Teruel, J., \& Barrio, A. (2021). The asymmetrical effect of polarization on support for independence: The case of Catalonia. Politics and Governance, 9(4), 412-425.

Roeder, P. G. (2007). Where nation-states come from: Institutional change in the age of nationalism. Princeton University Press.

Sandel, M. J. (1984). Liberalism and its critics. NYU Press. Sanjaume-Calvet, M. (2020). Moralism in theories of secession: A realist perspective. Nations and Nation- alism, 26(2), 323-343.

Sanjaume-Calvet, M. (2021). Plebiscitarianism revisited: A typology of independence referendums. Canadian Journal of Political Science/Revue Canadienne de Science Politique. Advance online publication. https:// doi.org/10.1017/S0008423921000421

Siroky, D. S., Mueller, S., \& Hechter, M. (2016). Centerperiphery bargaining in the age of democracy. Swiss Political Science Review, 22(4), 439-453.

Sorens, J. (2012). Secessionism: Identity, interest, and strategy. McGill-Queen's University Press.

Webb, M. J. (2015). The importance of predecessor centers of sovereignty and processes of state formation in explaining secession. Defense \& Security Analysis, 31(1), 22-34. https://doi.org/10.1080/14751798. 2014.989711

Wood, J. R. (1981). Secession: A comparative analytical framework. Canadian Journal of Political Science/Revue Canadienne de Science Politique, 14(1), 107-134.

\section{About the Authors}

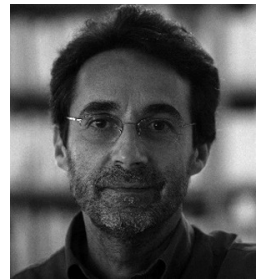

Ferran Requejo is professor of political science at Pompeu Fabra University (Barcelona). He has been awarded the Rudolf Wildenmann, the Ramon Trias Fargas, and the Spanish Political Science Association prizes for best book. Furthermore, he has been director of the Self-Government Studies Institute, member of the Spanish Electoral Board of the Executive Committee of the ECPR and member of the Comparative Federalism Research Committee (IPSA).

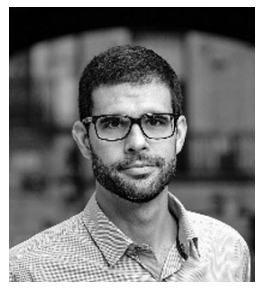

Marc Sanjaume-Calvet is assistant professor of political theory in the Department of Political and Social Sciences at Pompeu Fabra University (Barcelona). He is a member of the Political Theory Research Group and coordinator of the Masters in Current Democracies. Former assistant professor at Open University of Catalonia, advisor at Self-Government Studies Institute-Institut d'Estudis de I'Autogovern, and visiting researcher at Edinburgh University (Scotland) and Laval University (Quebec). 